\title{
IMPLEMENTATION OF RIVER ELECTRONIC NAVIGATION SYSTEMS AND ONSHORE INFORMATION SERVICES ON THE INLAND WATERWAYS OF UKRAINE
}

\section{ВПРОВАДЖЕННЯ РІЧКОВИХ ЕЛЕКТРОННИХ НАВІГАЦІЙНИХ СИСТЕМ ТА БЕРЕГОВИХ ІНФОРМАЦЙНИХ СЛУЖБ НА ВНУТРІШНІХ ВОДНИХ ШЛЯХАХ УКРАЇНИ}

\author{
J. Buravtsova ${ }^{1}$, PhD student \\ Ю.О. Буравцова ${ }^{\mathbf{1}}$, acnipaнm \\ ${ }^{1} N U \ll O M A »$, Ukraine \\ ${ }^{1} H У « O M A »$, Украӥна
}

\begin{abstract}
Within the framework of the existing ideas on the solution of problematic navigation situations related to ensuring the safety of vessel's navigation, an assessment was made for determining the impact of e-Navigation on the level of safety, based on using current and important navigational information. The article shows the correct selection of the current and main components of navigational information, taking into account their interconnection, as well as increasing the assessment of the safety indicators of the ship's navigation. In order to develop inland navigation and meet the standards of the countries of the European Union, Ukraine must use modern systems to improve the level of safety on the inland waterway $(I W W)$. The technical plan was developed, in particular, on the basis of assessment of the impact of e-navigation on reducing the number of navigational accidents for SOLAS and non-SOLAS vessels (the International Convention for the Safety of Life at Sea). The article is aimed at theoretical assessment of the potential of e-Navigation on IWW of Ukraine by examining and applying the IMO methodology for increasing navigational level. A case study was conducted on the concept of e-Navigation as a model to assess the impact of $e$-Navigation on the vessel's safety.

All segments of the transport process and logistics are integrated, as evidenced by global transport trends. As a result, a new type of transport infrastructure began to develop - transport, logistics and freight transport complexes, which formed a united system of interaction. The scientific and technical policy of the transport industry allows for the development of science, innovative technologies and the training system in all areas, including the encouragement of the development and implementation of innovative intelligent transport systems that ensure efficient management of traffic flows and vehicles, which suggests the main goal of improving quality of transport services. In connection with the constant technological development of the industry, it seems possible to further development of e-Navigation strategy as extremely accurate and systematic in ensuring the safety of navigation with prevention dangerous incidents, environmental protection and cost-effective systems. For the implementation of e-Navigation on the IWW of Ukraine, appropriate recommendations were developed.
\end{abstract}

Keywords: e-Navigation, IWW, safety level, recommendations.

\section{Постановка проблеми в загальному вигляді та її зв'язок із важливими науковими чи практичними завданнями}

Існує чітка та вагома потреба у забезпеченні членів екупажу судна та берегових працівників, відповідальних за безпеку морського транспорту, сучасними надійними засобами, оптимізованими для прийняття найкращих рішень 3 метою покращення надійності 
навігації, комунікації та їх зручності для користувача. Однак, якщо існуючі технологічні досягнення надалі відбуватимуться без належної координації, є ризик того, що майбутньому розвитку систем морської навігації заважатиме недостатня стандартизація їх використання, несумісність між суднами та зростаючий рівень складності.

Аналіз останніх досліджень і публікацій, в яких започатковано розв'язання даної проблеми і виділення невирішених раніше частин загальної проблеми

При написанні роботи, були розглянуті дослідження, які пов’язані з вищезазначеною проблемою.

Дослідження деяких питань стосовно оцінки впливу інновацій на безпеку мореплавства розглянуті в статті [1]. Автори детально описують проблеми людського елемента в електронній навігації та підкреслюють важливість ефективного навчання кінцевих користувачів. Проте дані, які були підставою для програми навчання по зниженню людського фактору на сьогоднішній день вже застарілі і потребують оновлення. 3 цією метою аналіз аварійних ситуацій за останні п'ять років $є$ актуальним.

Перспективи е-Навігації в судноводінні розглянуті в роботі [2], де описується майбутнє даної системи, пов'язане 3 постійним технологічним проривом, що робить можливим подальший розвиток стратегії е-Навігації як гранично точної та системної структури в питаннях забезпечення безпеки мореплавства.

Дослідження, що стосуються е-Навігації та без екіпажного судноводіння, розглянуті в роботі [3], як найбільш перспективний напрямок застосування інформаційних технологій у галузі морського та річкового транспорту. Однак автори даної роботи не розглядають зовнішній людський фактор впливу на безперервну роботу автономних суден, що висвітлено у моїй роботі.

Робота [4] описує розробку цифрового індексу PIC на внутрішніх водних шляхах України в процесі впровадження інформаційного порталу Свропейського Союзу.

Робота [5] спрямована на оцінку того, як і якою мірою електронна навігація сприяє зниженню аварійності суден. Дослідження фокусується на потенційних ефектах електронної навігації на основі наборів інструментів електронної навігації та послуг SMART-навігації для суден, що піддають та не підпадають під Конвенцію СОЛАС. Данні дослідження $\epsilon$ актуальними, але потребують доробки на базі сучасних технологій.

У статті [6] описується планування розгортання різних інструментів електронної навігації у Віслінській затоці від наземної системи доповнення до віртуальних та синтетичних засобів навігації, батиметрії з високою роздільною здатністю та передового навігаційного програмного забезпечення для лоцманів.

Огляд архітектури електронної навігації представлений у статті [7], де також описано функціональний аналіз взаємозв'язку всіх підрозділів системи е-Навігації. Ці дослідження потребують доповнення у сфері оцінки зниження потенційних людських втрат за допомогою параметрів управління ризиками.

В роботі [8] представлені бачення, розвиток та цілі стратегії щодо підвищення інформованості та безпеки за допомогою е-Навігації, описується стратегія імплементації системи, визначаються недоліки у продуктивності, а також демонструються потреби користувачів.

Використовуючи досвід вище зазначених робіт, у статті представлена стратегія імплементації системи е-Навігації на ВВШ України, за для підвищення рівня безпеки та підтвердження статусу морської держави.

\section{Формулювання цілей статті}

Метою даної роботи є стратегічний розгляд та розробка пропозицій щодо впровадження річкових електронних навігаційних систем та берегових інформаційних служб на внутрішніх водних шляхах (ВВШ) України задля підвищення безпеки судноплавства та зменшення кількості помилок і пов'язаних з ними аварій. 


\section{Виклад матеріалу дослідження 3 повним обгрунтуванням отриманих наукових результатів}

Система е-Навігації залежить від двох зовнішніх факторів, а саме Всесвітньої радіонавігаційної системи (Резолюція А.953) [9] та внутрішньої інфраструктури на березі та на борту суден.

Згідно 3 річним звітом про розслідування в галузі безпеки на морі за 2020 рік, відзначається зниження загальної кількості повідомлень про морські аварії за останні п'ять років [10]. Це пов'язано з впровадженням сучасних систем, таких як е-Навігація, яка полегшує роботу судноводіїв, шляхом передачі даних на судна та на берег за допомогою більш ефективної організації, а також покращує обмін даними та зв'язку між суднами та берегом. Отриману загальну характеристику можна застосувати до ВВШ України. На рисунку 1 зображено графік статистики морських аварійних подій за 2016 - 2020 рік.

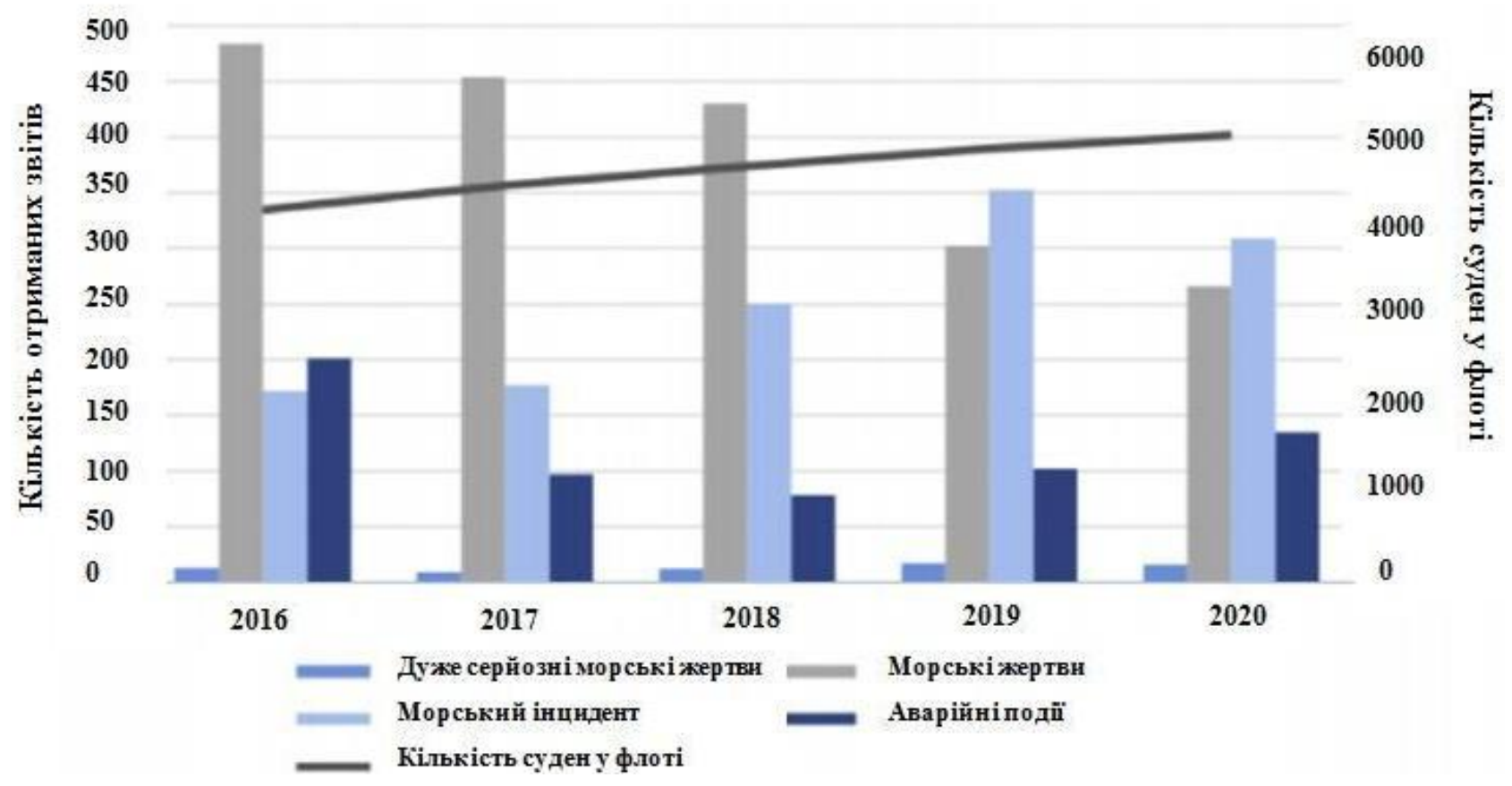

Рис. 1. Графік статистики аварійності за 2016 - 2020 роки

Основні набори інструментів е-Навігації для зниження аварійності суден полягає в наданні додаткових спеціальних послуг, які спрямовані на запобігання потенційних причин аварій заздалегідь на основі використання актуальної статистики в реальному часі та даних берегової станції стосовно місцевої ситуації. Ці послуги включають наступні етапи:

- Підтримка прийняття рішень для уникнення аварій;

- Аналіз факторів безпеки на основі загальних даних;

- Надання інформації про безпеку для суден;

- Надання послуги потокової передачі електронних навігаційних карт;

- Комплексне розпізнавання та реагування на всі навігаційні зони;

- Надання інформації про незаконну та нерегульовану промислову діяльність;

- Надання інформації про розлив нафти;

- Підтримка заходів щодо запобігання незаконному скидання відходів / забруднюючих речовин із суден;

- Підтримка іншої діяльності, пов'язаної з морською безпекою.

Відповідно до плану реалізації стратегії е-Навігації (NCSR 1/28 Додаток 7) [11], ступінь зниження аварійності 65\%, була оцінена за допомогою наступних кроків на основі офіційної оцінки безпеки IMO FSA (Formal Safety Assessment ): 
1. Виявлення проблем 3 точки зору безпеки мореплавання: визначення потреб користувачів, аналіз недоліків;

2. Визначення наборів інструментів електронної навігації для зниження ризику RCO (Risk Control Options );

3. Оцінка ризику навігаційних аварій на основі результату аналізу даних;

4. Оцінка загальної потенційної загибелі людей PLL (Potential Loss of Lives);

5. Розподіл оцінених ризиків між можливими причинами аварії.

В таблиці 1 визначено оцінку зниження потенційних людських втрат шляхом впровадження параметру управління ризиками.

Таблиия 1. Визначення оичінки зниження потенційних людських втрат за допомогою параметрів управління ризиками

\begin{tabular}{|c|c|c|c|c|}
\hline № & \multicolumn{2}{|c|}{ Варіанти управління ризиками } & \multirow{2}{*}{$\begin{array}{l}\text { Зменшенн } \\
\text { я PLL } \\
2.1 \mathrm{E}-04\end{array}$} & \multirow{2}{*}{$\begin{array}{c}\begin{array}{c}\text { Загальне } \\
\text { зменшенн } \\
\text { я PLL }\end{array} \\
14 \%\end{array}$} \\
\hline 1 & $\mathrm{RCO} 7$ & $\begin{array}{l}\text { Стандартизація компонування навігаційних містків і } \\
\text { робочих станцій }\end{array}$ & & \\
\hline 2 & $\mathrm{RCO} 1$ & $\begin{array}{l}\begin{array}{l}\text { Інтеграція навігаційної } \\
\text { покращення iнформації, } \\
\text { забезпечення }\end{array} \\
\end{array}$ & $1.7 \mathrm{E}-04$ & $11 \%$ \\
\hline 3 & $\mathrm{RCO} 2$ & Керування оповіщеннями на містку & $1.5 \mathrm{E}-04$ & $10 \%$ \\
\hline 4 & $\mathrm{RCO} 3$ & $\begin{array}{l}\text { Автоматизована та стандартизована звітність із } \\
\text { судна на берег }\end{array}$ & $1.3 \mathrm{E}-04$ & $8 \%$ \\
\hline 5 & $\mathrm{RCO} 4$ & Покращення надійності бортових систем & $1.2 \mathrm{E}-04$ & $8 \%$ \\
\hline 6 & RCO 5 & Стандартизований режим & $1.1 \mathrm{E}-04$ & $7 \%$ \\
\hline 7 & $\mathrm{RCO} 6$ & Покращені берегові послуги & $1.1 \mathrm{E}-04$ & $7 \%$ \\
\hline \multicolumn{3}{|c|}{ Підсумок } & & $65 \%$ \\
\hline
\end{tabular}

Значенням параметру «рівень зниження ризику - 65\%», який був розрахований IMO, $є$ не швидкість зменшення кількості аварій, а швидкість зменшення відсотка кожної конкретної прямої причини, яка повинна бути зменшена в параметрі контролю ризиків 3 точки зору потенційної загибелі людей. Це означає, що коефіцієнт «65\%» повинен бути конвертований в фактичну ступінь зниження ризику в параметрі контролю за кожною прямою причиною, а також у фактичний обсяг аварій, який повинен бути зменшений серед всіх аварій. Таким чином, пропонується наступні формули для більш точного розрахунку ефективності еНавігації з урахуванням реальних умов, пов'язаних 3 аваріями та параметрами контролю ризиками:

$$
\begin{aligned}
S_{\text {інц }} & =\sum\left(r_{\mathrm{aв}}+a_{\text {зр }}\right) \\
& =\sum\left(r_{\mathrm{aв}}+k+a_{\text {зр }}\right) \\
& =\sum k\left(r_{\mathrm{aв}}+a_{\text {лф }}+a_{\mathrm{T} 3}+a_{\text {зф }}\right)
\end{aligned}
$$

де: $S_{\text {інц }}-$ фактичний об'єм інцидентів, який повинен бути зменшений серед загальної кількості аварій; $r_{\text {ав }}$ - розподіл обраних аварій; $a_{\text {зр }}$ - фактичне зниження ризику для кожного випадку; $k$ - коефіцієнт (65\% для суден СОЛАС, 55\% для суден, що не підпадають під дію СОЛАС); $a_{\text {лф }}-$ зниження ризику кожної конкретної причини людського фактору; $a_{\text {тз }}-$ зниження ризику кожної конкретної причини технічного збою; $a_{\text {зф }}$ - зниження ризику кожної конкретної причини зовнішнього фактору. 
Наступним етапом $є$ визначення складових параметру контролю ризиків, задля можливості об'єднання таких дій до відповідних процесів. На рисунку 2 зображена схема процесу ідентифікації параметрів контролю ризику.

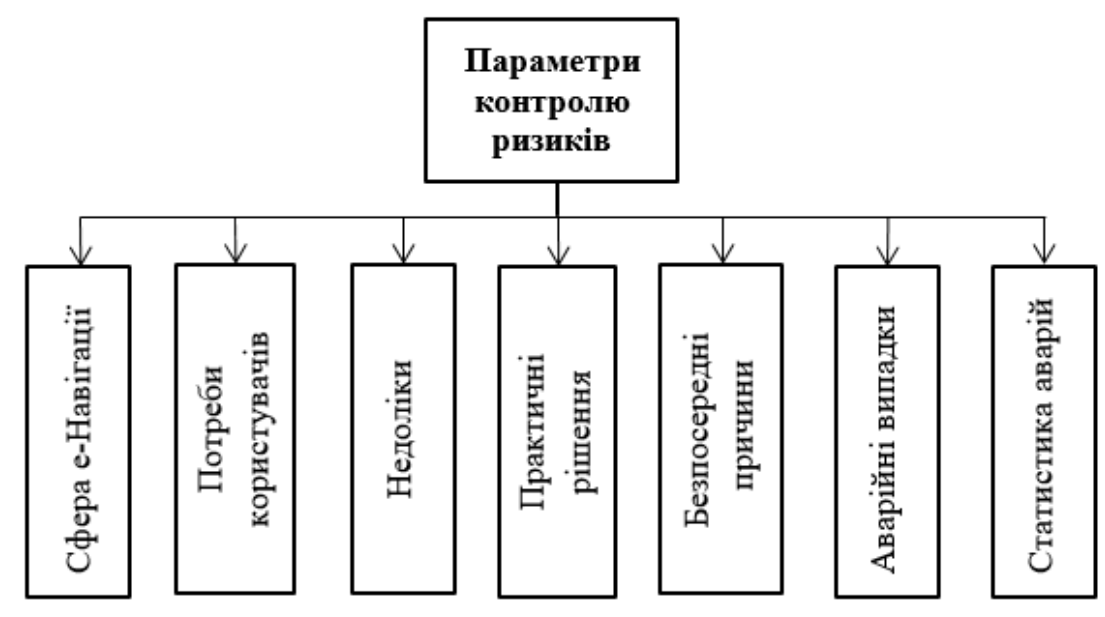

Рис. 2. Схема процесу ідентифікації параметрів контролю ризику

Для берегових технічних служб пропонується використовувати мережу передачі, що розподіляє дані, які використовуються береговими технічними службами системи е-Навігації. Вимоги щодо передавання даних залежать від специфіки технології берегових технічних служб системи. Наприклад, берегова радіолокаційна служба може вимагати наявності інших характеристик мережі передачі даних, аніж берегова служба автоматичної ідентифікаційної системи (AIC). Отже, індивідуальні вимоги щодо мережі передачі даних берегових технічних служб системи е-Навігація необхідно також інкапсулювати, оскільки це зменшує рівень складності.

На рисунку 3 зображені об’єкти, які можуть бути застосовані при впровадженні еНавігації на річці Дніпро.

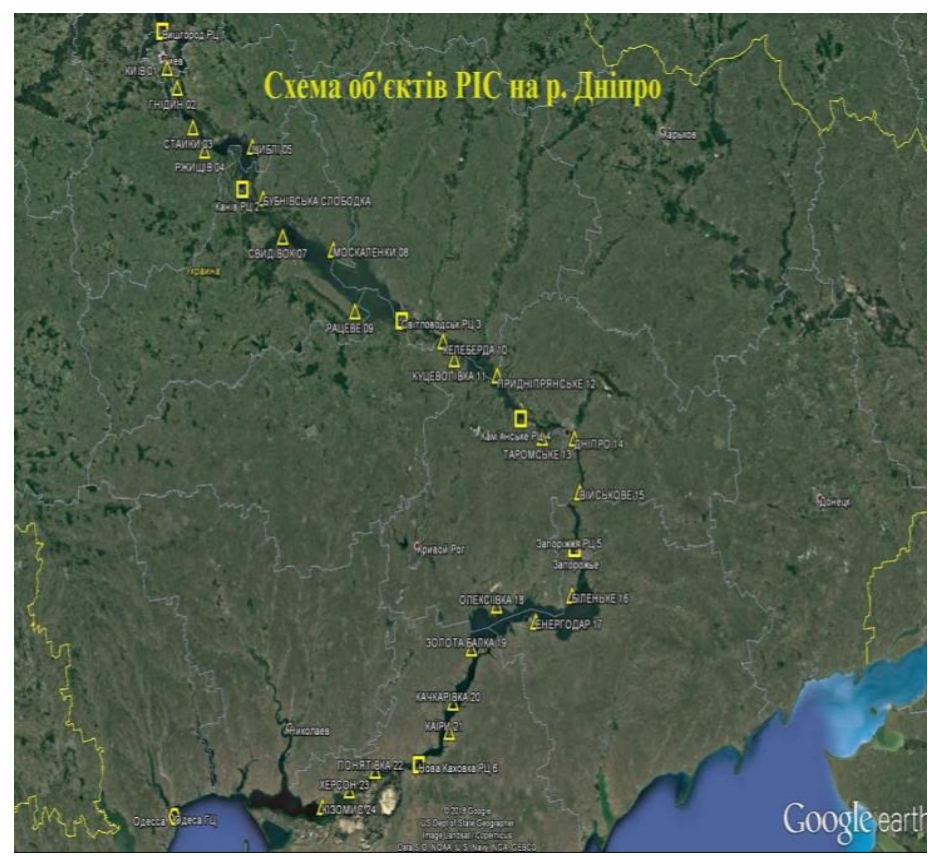

Рис. 3. Схема об'єктів річної інформаџійної служби (РІС) для впровадження еНавігащії на р. Дніпро 
Берегові оператори, як наприклад оператори системи радіозв'язку, оператори лоцманських станцій та оператори шлюзів, потребують прикладних програм користувача для виконання своїх завдань при співпраці 3 бортовими програмними додатками. . Для користувачів важливе значення мають функціональні зв'язки між береговими програмами користувача та бортовими програмами. Подібне налаштування взаємозв'язків застосовується й до програм судно-судно та берег-берег.Суднам необхідна інформація стосовно планування та здійснення маршрутів, оцінки навігаційних ризиків та узгодження з відповідними нормами. Ця інформація повинна надаватися згідно з загальною структурою даних, узгодженою на міжнародному рівні. Така структура даних суттєво важлива для обміну інформацією між береговими установами на регіональному та міжнародному рівнях. Слід враховувати вимоги до резервування, особливо щодо систем позиціонування.

Беручи до уваги вищезазначене, можна запропонувати план стратегічного впровадження е-Навігації, який являє собою наступні пріоритетні рішення:

1. Вдосконалена, гармонізована та зручна для використання конструкція ходового містка;

2. Засоби стандартизованого й автоматизованого створення звітів;

3. Поліпшена надійність, здатність до відновлення функцій і цілісність обладнання

ходового містку та навігаційної інформації;

4. Інтеграція та надання інформації, отриманої за допомогою комунікаційного обладнання на графічних дисплеях;

5. Вдосконалені комунікації портфеля послуг системи управління рухом суден (СУРС).

В пунктах 2, 4 і 5 точка фокусування спрямована на ефективну передачу морської інформації та даних відповідним користувачам (судно - судно, судно - берег, берег - судно та берег - берег). Пункт 1 і 3 сприяють ефективному на практиці застосуванню даних та інформації на суднах.

Очевидно, що впровадження програм на основі електронної навігації, як очікується, значно скоротить кількість аварій. Слід враховувати, що для забезпечення успіху програми еНавігації на ВВШ України, впровадження нових систем має бути ретельно підготовленим, включаючи навчання кінцевих користувачів правильному поводженню з новими рішеннями 3 набору інструментів і їх використанню. Особливу увагу слід приділяти оперативній інтеграції функцій і послуг в існуючі режими СУРС, що забезпечує розширені послуги електронної навігації для судноводіїв, лоцманів та інших кінцевих користувачів.

\section{Висновки і перспектива подальшої роботи по даному напрямку}

Найважливішою частиною парадигми загальної берегової системи е-Навігації є об'єктно-орієнтований процес розробки. Підсумовуючи вищезазначене розроблені рекомендації щодо впровадження річкових електронних навігаційних систем та берегових інформаційних служб на ВВШ України, які описують методологію, що застосовується до існуючого інженерного завдання у такому поетапному процесі:

1. Перерахувати та з'ясувати всі зазначені інформаційні потреби й пов'язані одиниці інформації для загальної берегової системи е-Навігації в цілому;

2. Перерахувати та з'ясувати внутрішні вимоги для загальної берегової системи еНавігація в цілому з управлінської та технологічної точки зору, наприклад, вимоги до управління життєвим циклом і вимоги до використання ресурсів;

3. Використати інженерні методології для проведення інженерного аналізу вимог берегової системи е-Навігація;

4. Вивести основні системні вимоги шляхом використання подібностей між зазначеними інформаційними потребами різних користувачів, а також внутрішні вимоги, як зазначено вище;

5. Розробити макет загальної берегової системи е-Навігація, використовуючи окремі технічні служби е-Навігації в якості складових елементів;

6. Для кожної окремої важливої системної вимоги визначити взаємозв'язки відповідних 
індивідуальних технічних служб е-Навігації, необхідних для виконання конкретних важливих системних вимог;

7. Скласти проект точного функціонального опису окремої технології як технічної служби е-Навігації згідно з загальною моделлю служби е-Навігації:

8. Вивести всі вимоги до компонентів окремої технічної служби е-Навігації;

9. Об'єднати всі зазначені вище описи у документальній методології та підготувати до подання на перевірку управління якості.

Також були встановлені напрями розвитку, необхідні щодо впровадження річкових електронних навігаційних систем на ВВШ України. При впровадженні концепції е-Навігації доцільним є розгляд наступних аспектів:

1. Загальні аспекти, пов'язані з береговими структурами, включаючи визначення відповідних вимог берегових користувачів, а також аспекти навчання персоналу берегових установ;

2. Вдосконалення берегових програмам користувачів, наприклад, системи радіозв'язку, системи AIC засобів навігаційного обладнання (ЗНО), та інших програм для внутрішніх водних шляхів;

3. Вдосконалення берегових технічних служб системи е-Навігації, таких як радіолокаційна служба, служба АIC, служба візуальних ЗНО тощо;

4. Вдосконалення технологій зв'язку.

В наступних дослідженнях планується більш детально розглянути вищевказані аспекти.

\section{ЛIТЕРАТУРА}

1. D. Patraiko, P. Wake, "E-Navigation and the Human Element," Gdynia Maritime University, doi:10.1201/9780203869345.ch5, 2010.

2. И.И. Варенич, “Концепция е-Navigation - будущее безопасного мореплавания," ОНМА Судноплавство: перевезення, технічні засоби, безпека, сс. 109-111, 2014.

3. С.А. Шишкин, "Перспективы и проблемы реализации безэкипажного судоходства," ХДМА Сучасні інформаційні та інновачійні технологї на транспорті, сс. 18-21, 2017.

4. A. Raynov, M. Kulakov, I. Medvedieva, J. Oleynik, "Development of a digital RIS index in Ukraine's inland water-ways in the process of implementing the information portal of the European Union," Proc. of 24th International Scientific Conference Transport Means, Scopus, 2020, pp. 785-789.

5. Sun-Bae Hong, "A study on the effects of e-Navigation on reducing vessel accidents," The Maritime Commons: Digital Repository of the World Maritime University, 2015 [Online]. Available: https://commons.wmu.se/all_dissertations/502/ [Accessed: Oct. 18, 2021].

6. A. Weintrit, J. Pietraszkiewicz, W. Piotrzkowski, W. Tycholiz, "E-Navigating in highlyconstrained waters: a case study of the Vistula Lagoon," Cambridge University Press (CUP), doi:10.1017/S0373463320000661, 2021.

7. M. Coric, A. Gudelj, Z. Lusic "E-Navigation Architecture Overview and Functional Connection Analysis," University of Split, doi:10.17818/NM/2019/3.4, 2019.

8. J. Hagen, "Implementing e-Navigation (Technology and Applications Series)," Boston and London: Artech House, 2017. [E-book] Available: https://www.twirpx.com/file/3002868/ [Accessed: Oct. 27, 2021].

9. International Maritime Organization, "World Wide Radio Navigation System Resolution A.953(23)," International Maritime Organization, 2003. [Online]. Available: http://rise.odessa.ua/texts/A953_23e.php3 [Accessed: Oct. 28, 2021].

10. C. Dominguez-Pery, L. Vuddaraju, I. Corbett-Etchevers, R. Tassabehji, "Reducing maritime accidents in ships by tackling human error: a bibliometric review and research agenda," Journal 
of Shipping and Trade, 2021. [Online]. Available: https://jshippingandtrade.springeropen.com/articles/10.1186/s41072-021-00098-y [Accessed: Oct. 31, 2021].

11. International Maritime Organization, "Draft e-Navigation strategy implementation plan NCSR 1/28 Annex 7," Maritime Safety Committee. [Online]. Available: https://iho.int/uploads/default/n/c/ncsr1-28-annex-7.pdf [Accessed: Oct. 31, 2021].

\section{REFERENCES}

1. D. Patraiko, P. Wake, "E-Navigation and the Human Element," Gdynia Maritime University, doi:10.1201/9780203869345.ch5, 2010.

2. I.I. Varenich, "Kontseptsiya e-Navigation - budushchee bezopasnogo moreplavaniya," ONMA Sudnoplavstvo: perevezennya, tekhnichni zasobi, bezpeka, ss. 109-111, 2014.

3. S.A. Shishkin, "Perspektivy i problemy realizatsii bezekipazhnogo sudokhodstva," KhDMA Suchasni informatsiyni ta innovatsiyni tekhnologiï na transporti, ss. 18-21, 2017.

4. A. Raynov, M. Kulakov, I. Medvedieva, J. Oleynik, "Development of a digital RIS index in Ukraine's inland water-ways in the process of implementing the information portal of the European Union", Proc. of 24th International Scientific Conference Transport Means, Scopus, 2020, pp. 785-789.

5. Sun-Bae Hong, "A study on the effects of e-Navigation on reducing vessel accidents," The Maritime Commons: Digital Respository of the World Maritime University, 2015 [Online]. Available: https://commons.wmu.se/all_dissertations/502/ [Accessed: Oct. 18, 2021].

6. A. Weintrit, J. Pietraszkiewicz, W. Piotrzkowski, W. Tycholiz, "E-Navigating in highlyconstrained waters: a case study of the Vistula Lagoon," Cambridge University Press (CUP), doi:10.1017/S0373463320000661, 2021.

7. M. Coric, A. Gudelj, Z. Lusic "E-Navigation Architecture Overview and Functional Connection Analysis," University of Split, doi:10.17818/NM/2019/3.4, 2019.

8. J. Hagen, "Implementing e-Navigation (Technology and Applications Series)," Boston and London: Artech House, 2017. [E-book] Available: https://www.twirpx.com/file/3002868/ [Accessed: Oct. 27, 2021].

9. International Maritime Organization, "World Wide Radio Navigation System Resolution A.953(23)," International Maritime Organization, 2003. [Online]. Available: http://rise.odessa.ua/texts/A953 23e.php3 [Accessed: Oct. 28, 2021].

10. C. Dominguez-Pery, L. Vuddaraju, I. Corbett-Etchevers, R. Tassabehji, "Reducing maritime accidents in ships by tackling human error: a bibliometric review and research agenda," Journal of Shipping and Trade, 2021. [Online]. Available: https://jshippingandtrade.springeropen.com/articles/10.1186/s41072-021-00098-y [Accessed: Oct. 31, 2021].

11. International Maritime Organization, "Draft e-Navigation strategy implementation plan NCSR 1/28 Annex 7," Maritime Safety Committee. [Online]. Available: https://iho.int/uploads/default/n/c/ncsr1-28-annex-7.pdf [Accessed: Oct. 31, 2021]. 